\title{
INNOVATIVE METHODS OF MARKETING MANAGEMENT OF LUXURY BRANDS FOR EXAMPLE GUCCI'S COLLABORATION WITH THE FIAT COMPANY
}

\author{
Anastazja Magdalena Kasztalska ${ }^{1}$
}

\begin{abstract}
Branding is a basic and necessary tool in marketing. Recognizable brands develop international trade, cooperation, and exchange of goods. Of late, luxury brands have entered a new level of marketing and customer interaction, whereas, previously, brands specializing in one sector of the economy, generally ignored others. Gucci is a luxury brand that has recently teamed up with FIAT, a company with a completely different profile to that of manufacturing in the apparel industry. The aim of this study was to establish whether customers buying products from Gucci were interested in its collaboration with the automotive industry and whether the Gucci brand had become more recognizable because of this cooperation. The conclusions were somewhat remarkable, with the Fiat 500, a product combining reliability and beautiful design, continuing to be immensely popular. In addition, the cooperation of both brands has brought large profits and a significant increase in awareness of both companies. Undoubtedly, the innovative marketing method of designing a new car model, in collaboration with a luxury brand, brings awareness to both brands. Further studies are likely regarding this unprecedented case of cooperation between a brand of luxury clothing and one of an automotive company.
\end{abstract}

UDC Classification: 005.3, 658, DOI: http://dx.doi.org/10.12955/cbup.v4.736

Keywords: Gucci, Fiat, Luxury, Automotive, management, marketing.

\section{Introduction}

The future of a luxury brands is a further intensive development and expansion into other market sectors. A growing amount of customers expects that the company to cater for their needs on many levels. Luxury brands meet the expectations of their customers, who, being satisfied with one kind of product, willing to buy other types of goods, it is important to be signed by the brand you trust and that implements their ideas regarding their own, developed and fostered the image. Brands create a coherent offer products that complement each other and form a unified whole, which is compatible with the character and style of the buyer and the objectives, mission and guiding idea in which brand believes and which performs a specific luxury brand or enter into cooperation with other well-known and respected company. Gucci brand has decided to cooperate with the Fiat brand.

\section{Gucci Brand and Fiat Brand}

A brand needs to be individual and distinctive in a way that differentiates it from another operating within a particular market sector (Jones and Slater, 1986). Today's large recognizable and trans-national brands involve personalities that are present in our culture and everyday life, such as sporting heroes, movie stars, and fictional characters. The way in which managers shape the brand image requires multiple strategies that are both practical and functional (Arnold, 1992).

The basic and the most important feature of a brand is its portrayal of a product that is separate and distinct from products offered by other organizations. Separateness is an integral component of the product, exemplified in design, packaging, and complementary services. However, it is a component that is directly responsible for the differentiation of the psychological aspect of the product as well. Products offered by the company, in a specific industry, are often very similar in terms of functionality, and the brand is the feature that makes the product unique and individual against others (Kotler, 1994).

Gucci is a luxury Italian brand of clothing and leather goods, and is part of the Gucci Group, which is owned by French company, Kering. The company, Gucci, was founded by Guccio Gucci in Florence in 1921. The company produces $€ 4.2$ billion worldwide. It was listed as one of the 45 most profitable brands according to the Interbrand rankings of 2008 (The Top 100 Brands, 2008). Gucci is undeniably the best-selling and most recognized Italian brand, with 278 stores directly operated worldwide and numerous wholesalers and exclusive department stores as points of sale for their goods. In 2015, the brand was valued at USD 12.4 billion (Gucci Brand Value, 2015). From January 2015, the creative director, and the person responsible for the management of the company, has been Alessandro Michele (Foley and Zarga, 2015).

Fabbrica Italiana Automobili Torino (FIAT) is the Italian automotive company, which has headquarters in Turin. This company, FIAT, was founded in 1899 by Giovanni Agnelli. It started producing cars July 11, 1899, with a

\footnotetext{
${ }^{1}$ Anastazja Magdalena Kasztalska, Department of Marketing, University of Economics in Katowice, anastazja.kasztalska@gmail.com
} 
group of founders, including Biscaretti Roberto di Ruffia and Giovanni Agnelli. On this day in Palazzo Bricherasia, the founding act of "Società Anonima Fabbrica Italiana di Automobili" in Turin was signed. Thirty shareholders bought capital of 800 thousand Lires. After the takeover in November 1899, existing manufactures of automotive vehicles, the Ceirano brothers in Corso Dante, started the production of vehicles under the Fiat brand in 1900s. The first vehicle was a Fiat brand "3 1/2 HP" (Fiala, 2010).

Today, FIAT is mainly engaged in the production of passenger cars and vans. It is a large industrial group that has focused its activities on the automotive industry. The company designs, manufactures, and sells trucks, buses, tractors, agricultural machinery, earthmoving machinery, engines, and in the past, aircraft (Podbielski, 1986).

On January 29, 2014, FIAT completed a five-year process of acquiring Chrysler. As a result of the acquisition, the company FIAT Chrysler Automobiles was formed with official headquarters in The Netherlands, and, for tax reasons, the operational center was located in the United Kingdom. The shares of the new company were traded on the stock exchange in New York and in Milan, with existing shareholders of FIAT offered shares at the ratio of 1:1 to buy into FIAT Chrysler Automobiles. In 2013, this company was the seventh largest producer of cars in the world (Balcet, Calabrese, \& Commisso, 2013).

\section{Cooperation of Gucci Brand with the Automotive Industry, and in Particular with the Fiat Brand}

Recently, the Gucci brand has become recognizable in the automotive industry, and the FIAT brand in the clothing industry. Before this arrangement, the Gucci brand collaborated with other car brands. Aldo Gucci expanded into new markets by signing an agreement with American Motors Corporation. A joint project involved AMC Hornet car and was the first to offer a special package of luxury finishes created by the famous Italian fashion designer. The Gucci version of the car had a red and green bar (hallmark brand) on the beige seats, interior door panels, and front fenders, while the initials "GG" were embossed in the headlining. The choice of exterior colors was limited to "snow white", "olive green", and "light green" (Iannacci, 2013).

In 1979 and 1980, Gucci entered into a cooperation with Cadillac and co-created Cadillac Seville, which was a mid-size luxury sedan. The hood was crossed with the initials "GG" and the roof was covered with a vinyl coating that had a distinctive Gucci pattern, while headrests and armrests also had a characteristic pattern with red and green stripes. Interestingly, the trunk contained a full set of suitcases and travel bags, made by Gucci (Hyde, 2015).

In 2011, with dual celebrations of the 150th anniversary of Italian unification and the 90th anniversary of the brand Gucci, Gucci and FIAT presented a joint edition, the Fiat 500 Gucci. This car was available in two versions: black and white. The black version had a shiny chrome interior, which sharply contrasted with white trimmings. The white version was finished in satin chrome in an ivory color, with black detailing that was a gentle contrast, compared with the black version ("Fiat 500 Cabrio by Gucci garners recognition as the 'best small convertible of the year' at SAMA convertible driver", 2012). The car had colossal popularity and a crowd of supporters. The cooperation of two brands enabled the undoubted success of both (Successful Fiat 500 by Gucci edition makes an encore in the US, 2013).

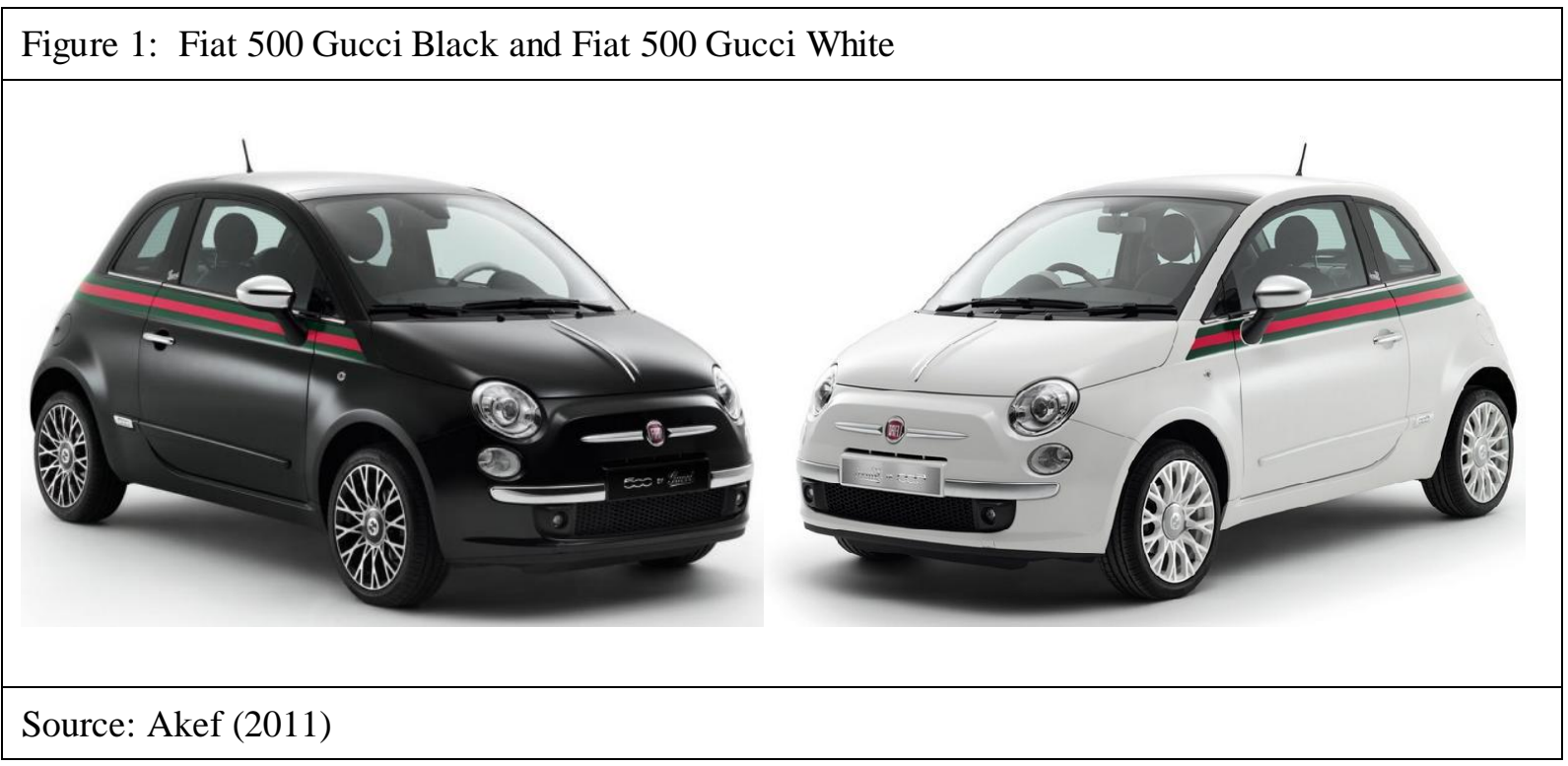




\section{Methodology}

The survey was based on primary data, through collecting and analyzing answers to questions previously selected. The survey involved an interviewer obtaining respondent's answers to the prepared questionnaire. The interviewer prepared and distributed the questionnaire, which was appropriately arranged, grouped, and formulated with questions to be answered by respondents (the person answering the questionnaire; Holbrook, 2005).

The survey focused on persons with qualities defined below that were selected by the interviewer. The survey omitted persons that did not have the features being studied. An example was the study of the phenomenon of luxury Gucci car, where respondents were the only owners and observers of those cars or the supporters of Gucci Company who had a certain opinion about this brand. Individuals, who for various reasons were not interested in the Gucci car, were excluded from the study because they did not have the relevant experience and clear opinion about the exclusive car design (Lynn, 2014).

The survey was sent by email to people who were actively participating in the life of Automotive and Fiat 500 owners, as well as fans of the Gucci brand. The survey had 100 people participating and was conducted in January and February 2016. Respondents had a high degree of freedom of expression, because they could modify the questions and add their own observations and comments. Subjects were men and women, diverse in age, with the youngest age being 21 years and the oldest 64. Age and gender was not a major determinant in selecting subjects. The main criterion was the wealth of a person, i.e., one who could afford to be an owner of luxury cars, for example, the Fiat 500 or other products with the Gucci label that were the consequence of cooperation between Gucci and Fiat.

Table 1: Results of the survey and data analysis

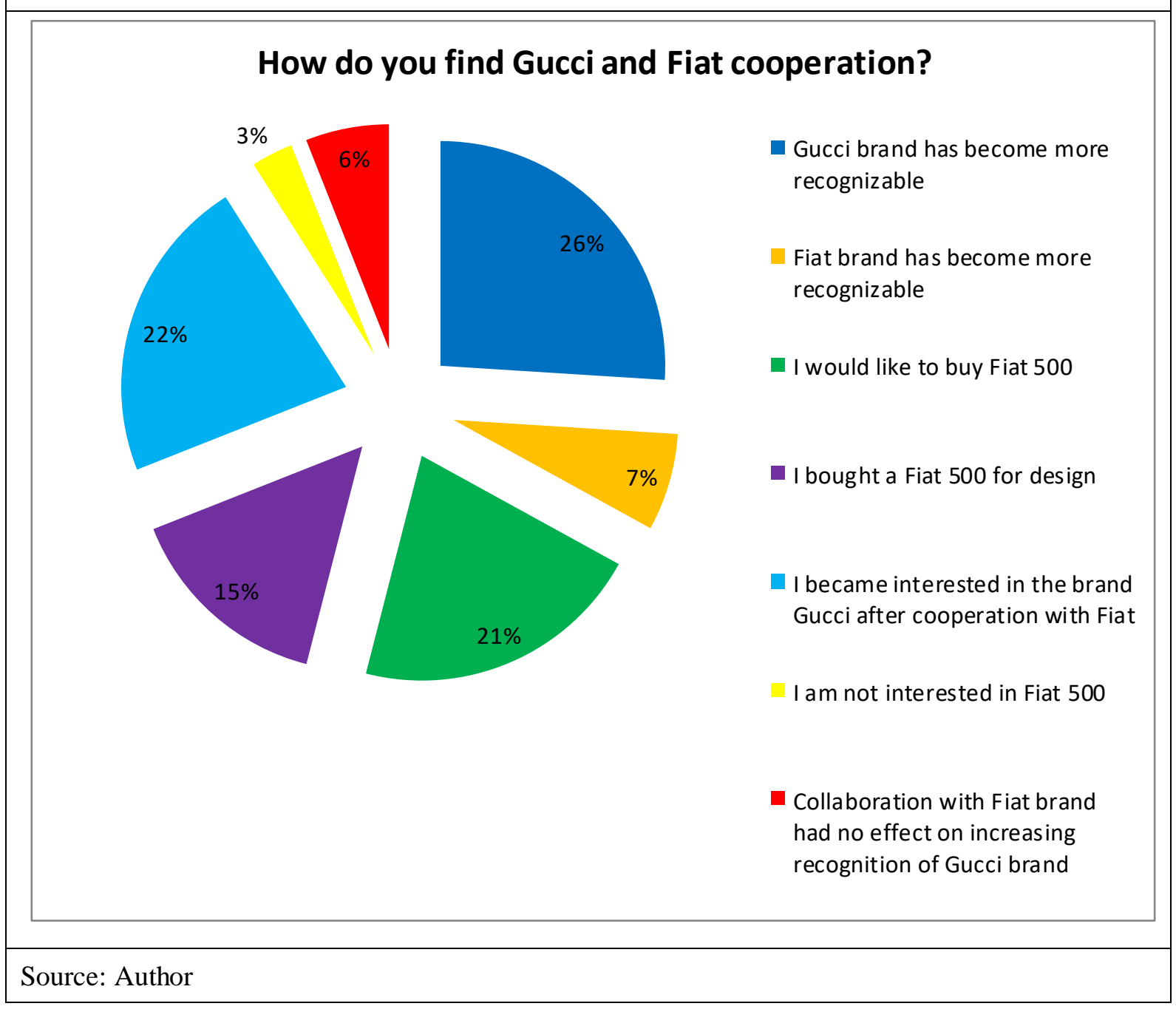


Most respondents indicated an increase in Gucci brand recognition, because of the cooperation between Gucci and the FIAT brand (26\%), and this may be associated with an earlier lack of interest in the clothing brand, especially among men. Another large group were interested in the brand after Gucci's cooperation with the automotive industry (22\%). Respondents indicated that innovation was the combination of design in luxury clothing brand and the design in the car. Another group, almost as large as the previous two, would have liked to or had planned to buy a Fiat 500 due to its unique design and because they identified with the brand Gucci (21\%). Some people were owners of the Fiat 500, and this group showed motives for purchasing, which were the cooperation of luxury brands to create their car, the desire to stand out, and the prestige of the Gucci brand awareness (15\%). A few people acknowledged that because of the cooperation between these two brands, Fiat has become more recognizable (7\%). It is worth noting that these respondents were young women who were far more interested in the clothing industry than automotive. Another group believed that the FIAT brand had not increased in popularity with the Gucci brand $(6 \%)$. This group consisted of men who were not interested in clothing brands, but respected the well-known FIAT brand. The smallest group were those who were generally not interested in the Fiat 500 or the brand Gucci $(3 \%)$. These people had cars of other makes and interest in other luxury brands.

\section{Conclusion}

Undoubtedly, marketing of luxury brands significantly increases a company's revenue. Survey research has shown that the cooperation of a clothing brand with an automotive brand, can increase the aw areness of both. It follows that managers should seek new solutions and ways of advertising that sometimes may be unconventional, for buyer interest in their products. Based on the survey results, one can draw the following conclusions.

Recognition of the brand influences one's decision to buy such. There is a correlation between the degree of a company's brand recognition and the company's revenue, and this suggests that the more the brand is known, the greater the generation of the company's profits.

Marketing luxury brands increases their visibility and their demand, e.g., through cooperation with a well-known automotive company (FIAT). Marketing should promote and build brand prestige in the eyes of customers so that it becomes a desirable brand and is "eagerly-selling". Demand for luxury goods is created by marketing that generates the need for prestige products which alone can satisfy the needs of customers. Fiat 500, which is the result of collaboration of two brands, was vastly popular and created huge profits for both brands.

Managers of luxury companies should constantly look for new marketing methods in order to gain new customers and maintain the interest of regular customers.

\section{References}

Akef, S. (2011, March 10). Fiat 500 by Gucci. Retrieved from: http://solmazinthecity.com/2011/03/10/fiat-500-by-gucci/ Arnold, D. (1992), The Handbook of Brand Management, New York: Addison-Wesley Publishing Company, p.2

Balcet, G., Calabrese, G., \& Commisso, G. (2013). Structuring and restructuring Fiat-Chrysler: Can two weak carmakers jointly survive in the new automotive arena? International Journal of Automotive Technology and Management, № 13(2), p. 183.

Close-Up Media, Inc. (2012). Fiat 500 Cabrio by Gucci garners recognition as the 'best small convertible of the year' at SAMA convertible drive. Travel \& Leisure Close - Up, Retrieved from http://search.proquest.com/docview/1021065060?accountid=45580

Fiala J. (2010). Encyclopedia of off-road vehicles, Bellona, Warsaw, p. 83.

Foley, B., \& Zargani, L. (2015, Jan 21), Gucci Confirms Alessandro Michele as Creative Director. Retrieved from http://wwd.com/fashion-news/designer-luxury/gucci-confirms-michele-as-creative-director-8127391

Gucci Brand value (2015). Retrieved from http://www.forbes.com/companies/gucci/

Holbrook, A. (2005) Methods for testing and evaluating survey questionnaires. Public Opinion Quarterly, № 69 (2), p. 333 336.

Hyde, J. (2015, Sep 28). Cadillac in NYC: Pure. Unadulterated. Autoweek, № 65, p. 56.

Iannacci, E. (2013, Mar 27). Off the runway and on the road. Maclean's, № 126, p. 73.

Jones, J. P., \& Slater J. S. (1986), What's in Name? Advertising and the Concept of Brands, Lexington: ME Sharpe Inc., p.29 Kotler, Ph. (1994), Marketing. Analysis, planning, implementation, monitoring, Warsaw: Gebethner and Company, p. 410411.

Lynn, P. (2014) Longer interviews may not affect subsequent survey participation propensity. Public Opinion Quarterly, № 78 (2), p. 500.

Podbielski, Z. (1986), Italian vehicles. In: Z. Podbielski, Discovering cars all around the world, Warsaw: WKit, p. 65-142.

Successful fiat 500 by Gucci edition makes encore in US. (2013). Travel \& Leisure Close - Up, Retrieved from http://search.proquest.com/docview/1367912320?accountid=45580

The 100 Top Brands (2008). Retrieved from http://www.bloomberg.com/ss/08/09/0918_best_brands/46.htm 